\title{
塑性の異なる細粒土と砂の混合土の 圧縮・せん断特性
}

\author{
小西 義夫 1 -兵動 正幸 2 ・伊東 周作 3 \\ 1正会員 (株)宇部建設コンサルタント(干757-0003 山口県山陽小野田市山野井3845) \\ E-mail:y-konishi@ukcnet.co.jp \\ 2正会員 山口大学大学院教授 理工学研究科環境共生系専攻(†755-8611 山口県宇部市常盤台2-16-1) \\ E-mail:hyodo@yamaguchi-u.ac.jp \\ 3正会員 基礎地盤コンサルタンツ(株)九州支社技術部(†814-0022 福岡県福岡市早良区原2-16-7) \\ E-mail:ito.shusaku@kiso.co.jp
}

\begin{abstract}
塑性の異なる3種の細粒土と1種の珪砂を種々の割合で混合することで，種々の塑性と細粒分含有率から なる混合土を作製した。このような混合土に対して，一連の定ひずみ速度圧密試験及び非排水三軸圧縮試 験を行った。その結果, 圧密及びせん断特性において, 混合土には砂骨格を主体とする挙動から細粒土主 体の挙動に移行するまでの領域が存在し，その境界となる細粒分含有率 $F_{\mathrm{c}}$ 及び粘土分含有率 $P_{\mathrm{c}}$ は，それぞ れ $F_{\mathrm{c}}=30 \%$ 及び $P_{\mathrm{c}}=15 \%$ 付近であることが分かった．また，細粒分含有率 $F_{\mathrm{c}}=30 \%$ 程度以下においては，シル 卜と砂が骨格構造を形成するという考えのもと, 砂・シルト骨格間隙比の概念を用いてせん断強度に及ぼ 寸影響要因について検討した。 その結果, 細粒土の種類によらず砂・シルト骨格間隙比とせん断強度は良 い相関性を示寸ことが明らかとなった。
\end{abstract}

Key Words : sand and fines mixture, fines content, clays content, void ratio, oedometer test, triaxial test, consolidation, undrained shear strength

\section{1. まえがき}

実務レベルの設計及び施工においては，多様な性質か らなる幅の広い範囲の土を取り扱わなければならないの が現状である，そこで，対象地盤の適切な土質定数を設 定する必要があるが，多くの場合，簡易的な方法として 対象地盤を砂地盤か粘土地盤のいずれかに区分して対応 がなされている.しかし，実際の地盤は，砂，シルト， 粘土が複雑に混入した状態で存在していることが一般的 である.これらの土のなかで，設計上砂か粘土に明確に 区分しがたい土を中間土 ${ }^{1)}$ と呼び，実務において，強度 定数の設定や液状化の判定など，取り扱いに苦慮してい る現状にある. そのため, 一般的に安全側での設計が行 われているのが現状であり，近年の建設事業に対するコ スト縮減が叫ばれている中，今後ますますこのような土 に関する研究が必要であるといえる.

ここでの砂と粘土の違いは, 構成する土粒子の粒径の 違いであり，それに起因して透水性や圧縮性が大きく異 なってくる. 砂と粘土の工学的性質の大きな違いとして, 盛土工事を例にすれば，砂地盤は常に排水状態であるの
に対して, 粘土地盤は短期の施工に対して非排水であり, 施工後に圧密による変形がゆっくりと生じる. 実地盤は 透水性や土縮性の異なる砂と粘土を含むために，単純に 砂地盤あるいは粘土地盤に区分して取り扱うことが困難 であるといえる.

混合土に関する研究は，これまで粒度組成やコンシス テンシー特性に着目し, 単調及び繰返しせん断強度を明 確にすることを目的に行われてきた。例えば，混合土の 圧縮特性に関寸る研究において鬼塚・吉武 ${ }^{21}$ は，細粒土 と砂を様々な割合で混合した混合土について標準圧密試 験を行い，いずれの混合土も圧縮指数及び膨張指数と塑 性指数の関係が直線で表されることを報告している．同 様に中瀬ら ${ }^{31}$ は, 塑性指数の異なる海成粘土の圧縮指数 及び膨張指数と塑性指数の関係が，ほぼ直線関係で表さ れることを確かめている.

また, 単調なせん断挙動に関しては, 砂から粘土まで の一連の研究として, Trollope・Zafar ${ }^{4}$ は, 粘土と砂を 様々な割合で混合し作製した混合土の非排水三軸圧縮試 験の結果をもとに, 粘性土と砂質土の境界を示寸細粒分 含有率が約 20\%であると報告している. 
表-1 混合土の物理的性質一覧

(a) 鳥取シルト混合土

\begin{tabular}{|c|c|c|c|c|c|c|c|c|c|c|c|c|c|c|}
\hline 試料番号 & \begin{tabular}{|c|} 
細粒土:珪砂 \\
混合比 \\
\end{tabular} & 作製方法 & $\begin{array}{c}\text { 砂分含有率 } \\
S_{\mathrm{c}}(\%) \\
\end{array}$ & $\begin{array}{c}\text { 細粒分含有率 } \\
F_{\mathrm{c}}(\%) \\
\end{array}$ & $\begin{array}{c}\text { 粘土分含有率 } \\
P_{\mathrm{c}}(\%) \\
\end{array}$ & $\begin{array}{r}D_{50} \\
(\mathrm{~mm}) \\
\end{array}$ & $\begin{array}{l}\text { 土粒子密度 } \\
\rho_{\mathrm{s}}\left(\mathrm{g} / \mathrm{cm}^{3}\right)\end{array}$ & $\begin{array}{c}\text { 間隙比 } \\
e * \\
\end{array}$ & \begin{tabular}{|c|} 
砂骨格 \\
間隙比 $e_{s} *$
\end{tabular} & $\begin{array}{l}\text { 砂・シル下骨格 } \\
\text { 間隙比 } e_{\mathrm{sm}} * \\
\end{array}$ & \begin{tabular}{|c|} 
夜性限界 \\
$W_{\mathrm{L}}(\%)$ \\
\end{tabular} & \begin{tabular}{|c|} 
塑性限界 \\
$W_{\mathrm{P}}(\%)$ \\
\end{tabular} & $\begin{array}{c}\text { 塑性指数 } \\
I_{\mathrm{P}} \\
\end{array}$ & 記号 \\
\hline $\begin{array}{l}\text { TTR-100 } \\
\end{array}$ & 100:0 & 水中堆積法 & 2.5 & 97.5 & 6.0 & 0.023 & 2.665 & 1.28 & 88.47 & 1.38 & - & - & $\overline{\mathrm{NP}}$ & D \\
\hline \begin{tabular}{|l|} 
TTR-70 \\
\end{tabular} & $70: 30$ & 水中堆積法 & 31.7 & 68.3 & 4.2 & 0.029 & 2.661 & 0.71 & 4.25 & 0.75 & - & - & $\mathrm{NP}$ & \\
\hline \begin{tabular}{|l|} 
TTR-50 \\
\end{tabular} & $50: 50$ & 水中堆積法 & 51.2 & 48.8 & 3.0 & 0.093 & 2.659 & 0.53 & 1.99 & 0.58 & - & - & $\mathrm{NP}$ & $\Delta$ \\
\hline \begin{tabular}{|l|} 
TTR-30 \\
\end{tabular} & $30: 70$ & 水中堆積法 & 70.7 & 29.3 & 1.8 & 0.430 & 2.656 & 0.54 & 1.17 & 0.57 & - & - & $\mathrm{NP}$ & $\nabla$ \\
\hline \begin{tabular}{|l|} 
TTR-15 \\
\end{tabular} & $15: 85$ & 水中堆積法 & 85.4 & 14.6 & 0.9 & 0.631 & 2.654 & 0.63 & 0.90 & 0.64 & - & - & $\mathrm{NP}$ & $\Delta$ \\
\hline TTR-5 & $5: 95$ & 水中堆積法 & 95.1 & 4.9 & 0.3 & 0.794 & 2.653 & 0.70 & 0.79 & 0.71 & - & - & $\mathrm{NP}$ & () \\
\hline TTR -0 & $0: 100$ & 水中堆積法 & 100.0 & 0 & 0 & 0.858 & 2.652 & 0.69 & 0.69 & 0.69 & - & - & $\mathrm{NP}$ & $\otimes$ \\
\hline
\end{tabular}

(b) 小野田粘土混合土

\begin{tabular}{|c|c|c|c|c|c|c|c|c|c|c|c|c|c|c|}
\hline 試料番号 & $\begin{array}{c}\text { 細粒土:珪砂 } \\
\text { 混合比 } \\
\end{array}$ & 作製方法 & $\begin{array}{c}\text { 砂分含有率 } \\
S_{\mathrm{c}}(\%)\end{array}$ & \begin{tabular}{|c} 
細粒分含有葍 \\
$F_{c}(\%)$
\end{tabular} & $\begin{array}{c}\text { 粘土分含有率 } \\
P_{\mathrm{c}}(\%) \\
\end{array}$ & $\begin{array}{r}D_{50} \\
(\mathrm{~mm}) \\
\end{array}$ & \begin{tabular}{|l} 
土粒子密度 \\
$\rho_{s}\left(\mathrm{~g} / \mathrm{cm}^{3}\right)$
\end{tabular} & $\begin{array}{c}\text { 間隙比 } \\
e * \\
\end{array}$ & $\begin{array}{c}\text { 砂骨格 } \\
\text { 間隙比 } e_{\mathrm{s}} *\end{array}$ & \begin{tabular}{|l|} 
砂・シルト骨格 \\
間隙比 $e_{\mathrm{sm}} *$ \\
\end{tabular} & $\begin{array}{c}\text { 液性限界 } \\
W_{\mathrm{L}}(\%) \\
\end{array}$ & $\begin{array}{c}\text { 塑性限界 } \\
W_{\mathrm{P}}(\%) \\
\end{array}$ & \begin{tabular}{|c} 
塑性指数 \\
$I_{\mathrm{P}}$
\end{tabular} & 記号 \\
\hline$\overline{\mathrm{ONC}}$ & $100: 0$ & 圧密 & 16.1 & 83.9 & 37.0 & 0.009 & 2.593 & 1.64 & 15.37 & 3.18 & 72.5 & 28.3 & 44.2 & \\
\hline \begin{tabular}{|l|}
$\mathrm{ONO}-70$ \\
\end{tabular} & $70: 30$ & 予圧密 & 41.3 & 58.7 & 25.9 & 0.037 & 2.649 & 1.28 & 4.53 & 2.08 & 54.0 & 23.4 & 30.6 & \\
\hline \begin{tabular}{|l|}
$\mathrm{ONO}-50$ \\
\end{tabular} & $50: 50$ & 予圧密 & 58.1 & 41.9 & 18.5 & 0.171 & 2.650 & 0.83 & 2.15 & 1.24 & 37.0 & 18.8 & 18.2 & $\Delta$ \\
\hline \begin{tabular}{|l|}
$\mathrm{ONO}-30$ \\
\end{tabular} & $30: 70$ & 予圧密 & 74.9 & 25.1 & 11.1 & 0.429 & 2.652 & 0.68 & 1.24 & 0.89 & 24.8 & 15.7 & 9.1 & $\nabla$ \\
\hline \begin{tabular}{|l|} 
ONO-15 \\
\end{tabular} & $15: 85$ & 水中堆積法 & 87.4 & 12.6 & 5.6 & 0.637 & 2.650 & 0.56 & 0.78 & 0.65 & - & - & NP & $\Delta$ \\
\hline ONO-5 & $5: 95$ & 水中堆積法 & 95.8 & 4.2 & 1.9 & 0.794 & 2.651 & 0.63 & 0.70 & 0.67 & - & - & $\mathrm{NP}$ & 0 \\
\hline ONO-0 & $0: 100$ & 水中堆積法 & 100.0 & 0 & 0 & 0.858 & 2.652 & 0.69 & 0.69 & 0.69 & - & - & $\mathrm{NP}$ & $\otimes$ \\
\hline
\end{tabular}

(c) 有明粘土混合土

\begin{tabular}{|c|c|c|c|c|c|c|c|c|c|c|c|c|c|c|}
\hline 試料番号 & $\begin{array}{c}\text { 細粒土:珪砂 } \\
\text { 混合比 } \\
\end{array}$ & 作製方法 & $\begin{array}{c}\text { 砂分含有率 } \\
S_{\mathrm{c}}(\%) \\
\end{array}$ & $\begin{array}{c}\text { 細粒分含有率 } \\
F_{c}(\%) \\
\end{array}$ & $\begin{array}{c}\text { 粘土分含有率 } \\
P_{c}(\%) \\
\end{array}$ & $\begin{array}{r}D_{50} \\
(\mathrm{~mm}) \\
\end{array}$ & $\begin{array}{l}\text { 土粒子密度 } \\
\rho_{\mathrm{s}}\left(\mathrm{g} / \mathrm{cm}^{3}\right)\end{array}$ & $\begin{array}{c}\text { 間隙比 } \\
e * \\
\end{array}$ & \begin{tabular}{|c|} 
砂骨格 \\
間隙比 $e_{\mathrm{s}} *$ \\
\end{tabular} & $\begin{array}{l}\text { 砂・シルト骨格 } \\
\text { 間䏚比 } e_{\mathrm{sm}} * \\
\end{array}$ & $\begin{array}{c}\text { 夜性限界 } \\
w_{\mathrm{L}}(\%) \\
\end{array}$ & $\begin{array}{c}\text { 塑性限界 } \\
W_{\mathrm{P}}(\%) \\
\end{array}$ & $\begin{array}{c}\text { 塑性指数 } \\
I_{\mathrm{P}} \\
\end{array}$ & 記号 \\
\hline \begin{tabular}{c|}
$\mathrm{ARI}-100$ \\
\end{tabular} & $100: 0$ & 予圧密 & 4.2 & 95.8 & 62.5 & 0.003 & 2.556 & 2.90 & 91.75 & 9.39 & 154.4 & 43.1 & 111.3 & (D) \\
\hline ARI-70 & $70: 30$ & 予圧密 & 32.9 & 67.1 & 43.8 & 0.009 & 2.585 & 2.26 & 8.91 & 4.80 & 112.5 & 30.2 & 82.3 & 7 \\
\hline ARI-50 & $50: 50$ & 予圧密 & 52.1 & 47.9 & 31.3 & 0.100 & 2.604 & 1.47 & 3.75 & 2.60 & 71.5 & 26.4 & 45.1 & $\Delta$ \\
\hline ARI-30 & $30: 70$ & 予圧密 & 71.3 & 28.7 & 18.8 & 0.430 & 2.623 & 1.13 & 1.99 & 1.62 & 56.3 & 22.8 & 33.5 & $\nabla$ \\
\hline ARI-15 & $15: 85$ & 予圧密 & 85.6 & 14.4 & 9.4 & 0.631 & 2.638 & 0.65 & 0.93 & 0.82 & - & - & $\mathrm{NP}$ & $\Delta$ \\
\hline ARI-5 & $5: 95$ & 水中堆積法 & 95.2 & 4.8 & 3.1 & 0.794 & 2.647 & 0.64 & 0.72 & 0.72 & - & - & $\mathrm{NP}$ & C) \\
\hline ARI -0 & $0: 100$ & 水中堆積法 & 100.0 & 0 & 0 & 0.858 & 2.652 & 0.69 & 0.69 & 0.69 & - & - & $\mathrm{NP}$ & $\otimes$ \\
\hline
\end{tabular}

$*$ 間隙比 $e$, 砂骨格間隙比 $e_{\mathrm{s}}$, 砂・シルト骨格間隙比 $e_{\mathrm{sm}}$ は三軸圧縮試験供試体のものを示す.

倉田・藤下 5)あるいは Georgiannou ら 9), 7)は，混合試料 を用いた一連の力学試験を行っている．倉田・藤下 ${ }^{5)}$ は， 砂質土と粘性土の区分において，砂分 $80 \%$ 以上を含む 土を砂質土と定義しており，その定義は，港湾の施設の 技術上の基準・同解説 ${ }^{8)}$ に取り入れられている.

さらに, Lade - Yamamuro" ${ }^{9)}$, 福江・大草 ${ }^{10)}$, 八尾・平 田 ${ }^{11)}$ ，大嶺・落合 ${ }^{12)}$ こより，混合土の粒子構造に着目し た研究が行われ，骨格及びマトリックスの変化に対し， それぞれの応力分担特性を評価した土全体の応力-ひず み関係の推定が行われている.

黄ら ${ }^{13)}$ は豊浦標準砂にシルトを混合した試料で液状化 試験及び静的三軸試験を実施し，シルト分の増加により 液状化強度が低くなることを示し，その要因は粒子間の ダイレイタンシー抵抗力が弱くなったためであると報告 している. 黄らは，それぞれの細粒分含有率で最大，最 小間隙比を求め，いずれの細粒分含有率においても相対 密度 $D_{\mathrm{r}}=50 \%$ となるよう突き固め法により供試体を作製 している. 細粒分を有する土の相対密度の測定が団粒化 などの理由により基準外であること，また実際に砂と細 粒土が相互にどのような役割を果たしたかについて言及 していないことなど課題を残している.

当研究グループは過去において，様々な土の骨格構造 及びせん断挙動の違いに対する実験的見地から, 砂から 粘土に至る広い範囲の土の力学特性を定量的に評価指標 を調べている.
伊東ら ${ }^{14)}$ は室内配合及び不撹乱試料を用いて，一連の 単調及び繰返し三軸試験を行い，砂粒子が骨格を成す領 域と, 細粒分がマトリックスを構成する領域の識別を行 っている. また吉本ら ${ }^{15}$ は，鳥取県西部地震の噴砂を採 取し，現行の示方書により液状化強度の検討を行い，細 粒分の混入する土に対する液状化の評価に塑性指数や粘 土分含有率の導入の必要性を指摘している.

山田ら ${ }^{16}$ は，砂混じり粘土及び塑性の異なる海成粘土 を用いて繰返しねじりせん断試験を行い, 細粒分含有率 や塑性指数，有効拘束圧，載荷周波数が動的変形特性に 及ぼす影響について検討している.さらに兵動ら ${ }^{177}$ は, 珪砂と海成粘土の混合土を作製し，等方及び異方圧密下 で一連の非排水繰返し三軸試験を行い，細粒分含有率を 変化させた砂・粘土混合土の初期せん断応力下での繰返 しせん断挙動について検討している.

本研究は砂から粘土へと変化していく広範な粒度範囲 の土を対象に，塑性の異なる細粒土と砂の混合土を作製 し，その圧縮性ならびにせん断挙動に及ぼす粗粒分と細 粒分あるいは粘土分の役割を明らかにすることを目的と した．実験には塑性の異なる 3 種類の細粒土と珪砂を混 合した試料を用いた，供試体の作製は，混合比に応じて 砂分が骨格を成す状態では水中堆積法(ウォーターセデ イメンテーション法), 細粒分がマトリックスを構成す る場合には, 試料圧密容器で予圧密法により行った。 こ れらの試料を対象に，定ひずみ速度圧密試験及び非排水 
三軸圧縮試験を行い，物理特性と圧縮特性ならびにせん 断特性の関連性について考察を行った。

\section{2. 試料及び実験方法}

\section{(1) 実験試料}

実験に用いた試料は，粗粒土と細粒土を配合して作製 した室内配合試料である．粗粒土は粒度調整した三河珪 砂であり最大，最小間隙比はそれぞれ， $e_{\max }=0.85$, $e_{\min }=0.52$ であった. 細粒土は鳥取県西部地震において竹 内工業団地で噴砂した鳥取シルト ${ }^{15)}$, 山口県小野田港よ り採取した小野田粘土及び佐賀県の六角川河口で採取し た有明粘土である。鳥取シルトは非塑性であり，小野田 粘土は $I_{\mathrm{p}}=44$ の中塑性, 有明粘土は $I_{\mathrm{p}}=111$ の高塑性粘土 である。

実験に用いた室内配合試料の混合比及び物理的性質を, 表-1 (a)〜 (c)に示す. 作製した配合試料は，鳥取シルト 混合土，小野田粘土混合土，有明粘土混合土であり，そ れぞれ粒度調整した珪砂と各細粒土を 7 種の質量混合比 で混合して作製したものである，表中の試料番号は，試 料中の細粒土の質量混合比に対応している. 用いた鳥取 シルト，小野田粘土，有明粘土は砂分をそれぞれ， $2.5 \%$, 16.1\%，4.2\%含んでおり，これらの砂分は珪砂と同等の 扱いをし，細粒分含有率からは除いて評価した。表中に 示寸間隙比 $e$, 砂骨格間隙比 $e_{\mathrm{s}}$, 砂・シル卜骨格間隙比 $e_{\mathrm{sm}}$ は三軸圧縮試験供試体の圧密前の值であり, 後述す るように, 砂骨格間隙比 $e_{\mathrm{s}}$, 砂・シルト骨格間隙比 $e_{\mathrm{sm}}$ は，砂及びシルトの骨格間隙量を表したものである.

図-1 (a)〜 (c)に，それぞれ鳥取シルト混合土，小野田 粘土混合土，有明粘土混合土の粒径加積曲線を示した. 四中に，各試料の細粒分含有率を示した。試料の細粒分 含有率は細粒土の混合比に応じて増加し，鳥取シルト混 合土はシルト分 $(0.075 \mathrm{~mm}$ 以下)を，有明粘土混合土は粘 土分 $(0.005 \mathrm{~mm}$ 以下)を多く含む特性を示している.

\section{（2）供試体作製}

本研究では，細粒分が多く塑性の高い混合土は，予圧 密法により供試体を作製し，細粒分が少なく低塑性また は非塑性の混合土は，予圧密法による供試体作製が困難 なため，水中堆積法で作製した。鳥取シルト混合土にお いては，すべての配合割合において非塑性であり，予圧 密法が不可能であったため，水中堆積法を採用した。水 中堆積法による供試体作成は，まず気乾状態の珪砂と細 粒土を所定の乾燥質量比で混合し，脱気水を満たした後 脱気槽に24時間放置した．次に，モールド内に脱気水を 半分程度張り，その中にモールド底からスプーンで試料

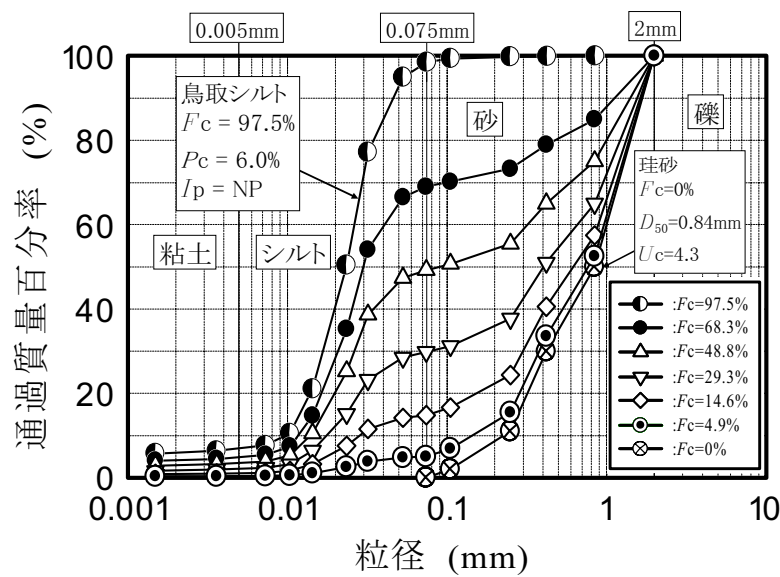

(a) 鳥取シルト混合土

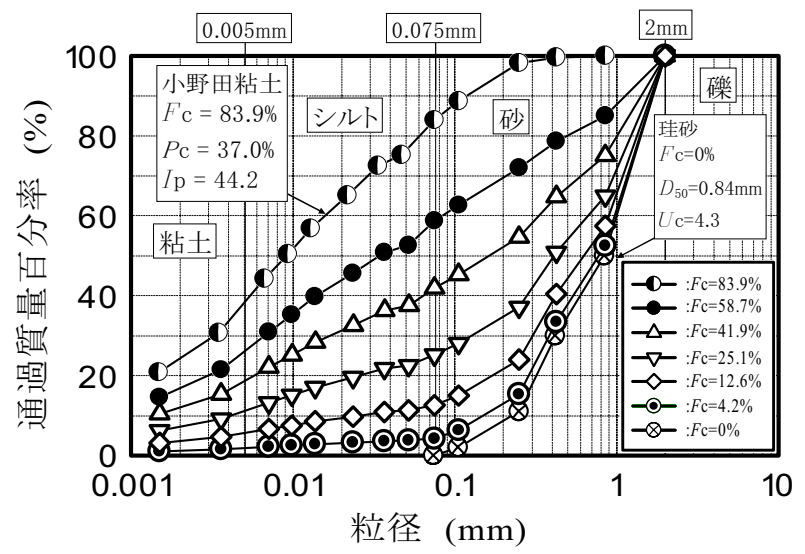

(b) 小野田粘土混合土

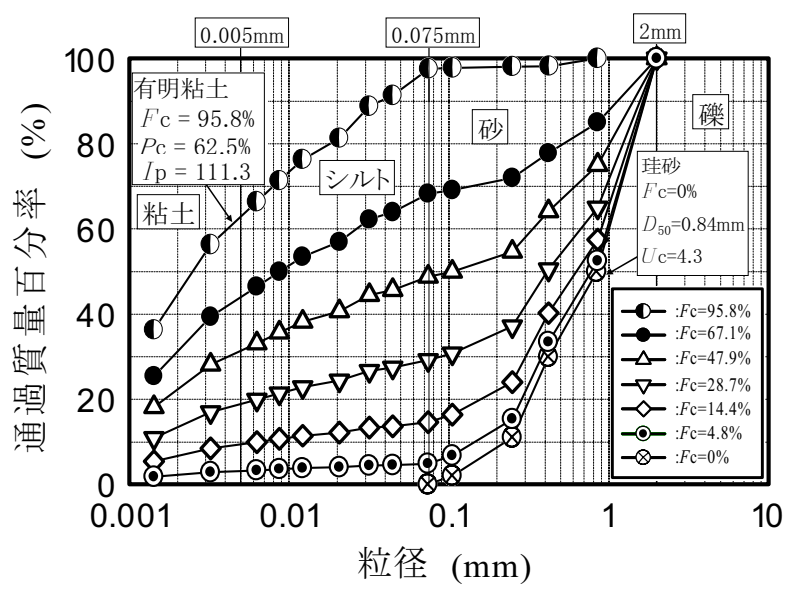

(c) 有明粘土混合土

図-1 混合土の粒径加積曲線

をゆっくりと入れ，分離しないよう投入した. このよう にして作成した珪砂のみの間隙比は $e=0.69$, 相対密度は $D_{\mathrm{r}}=48 \%$ であった。 ここで，本研究においては種々の細 粒分含有率の試料を取り扱うことから，相対密度の概念 は用いず，間隙比に基づいた考察を行う.

予圧密法では，まず調整した細粒土と珪砂を，所定の 乾燥質量比で均一になるように混ぜあわせ，含水比が液 性限界の2倍程度となるように調整を行った，次に，直 


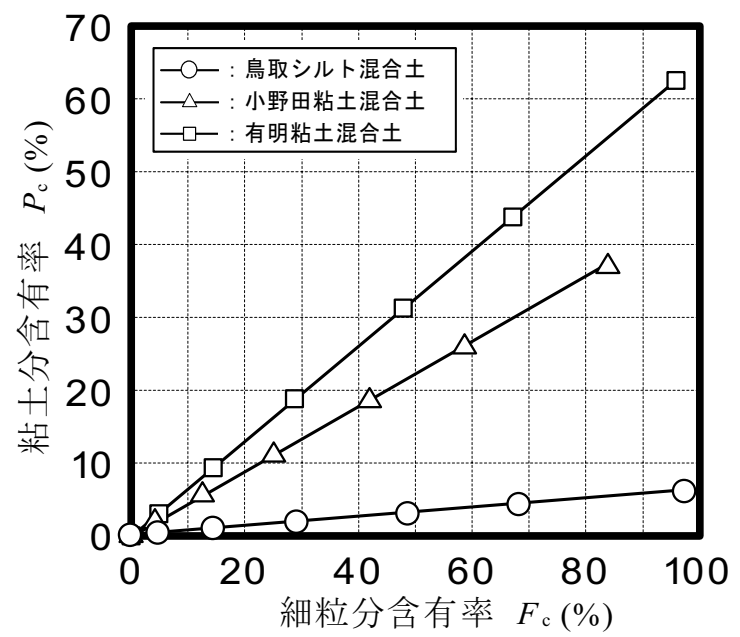

図－2 粘土分含有率 $P_{\mathrm{c}}$ と細粒分含有率 $F_{\mathrm{c}}$ の関係

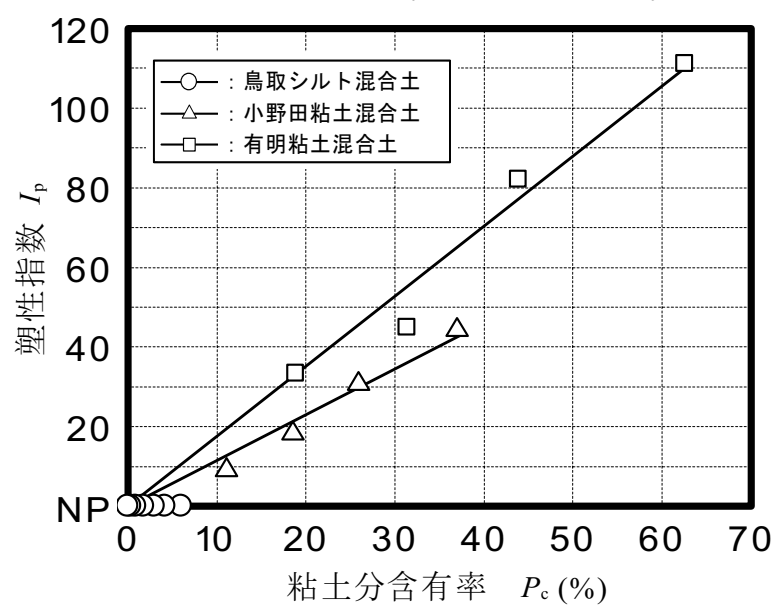

図-3 塑性指数 $I_{\mathrm{p}}$ と粘土分含有率 $P_{\mathrm{c}}$ の関係

径 $25 \mathrm{~cm}$ の予圧密装置のセル壁にシリコン離型剤を塗布 し，気泡ができないようにゆっくりと試料を投入した. さらに，鉛直圧密応力を $\sigma_{\mathrm{vc}}{ }^{\prime}=10 ， 20 \mathrm{kPa}$ とそれぞれ 1 日 ずつ段階的載荷により圧密した後，最終的に $\sigma_{\mathrm{vc}}{ }^{\prime}=50 \mathrm{kPa}$ で圧密を行い，3t法により圧密終了を確認した。

ここで，供試体作製過程において砂分が骨格構造を形 成する領域では，同一の細粒分含有率に対して，様々な 初期間隙比状態が存在する．本研究では，3 種類の活性 の異なる細粒土の強度変化をみることを目的としている ため，ここで作製した供試体は，それぞれの細粒分含有 率に対して，1 種類の密度状態になるようなものに限定 していることを付け加えておく.

\section{（3）実験方法}

本研究では，非排水三軸圧縮試験及び定ひずみ速度圧 密試験を行った。非排水三軸圧縮試験は直径 $5 \mathrm{~cm}$, 高さ $10 \mathrm{~cm}$ の円柱供試体を用いた。予圧密法により作製した 供試体は，上下端にろ紙，テフロンシート，ポーラスス トーンを取り付け，側面には圧密促進のためにペーパー ドレーンを巻き付けた。 その後三軸室にセットし,

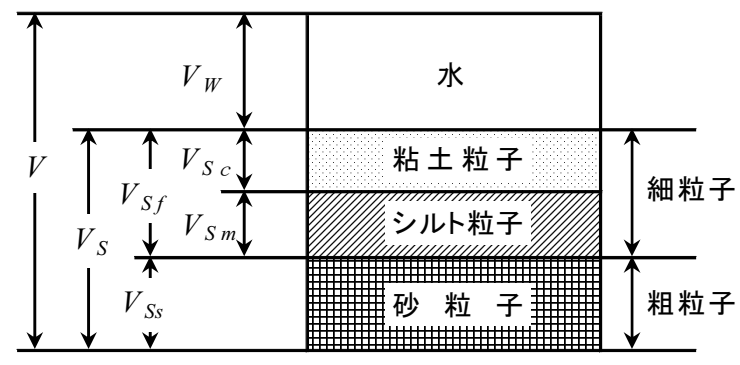

図-4 土の構造模式図

$200 \mathrm{kPa}$ の拘束圧まで段階的に等方圧を漸増して載荷し, 最終荷重段階では24時間圧密を行った。 せん断は, 非排 水状態で軸ひずみ速度 $0.1 \% / \mathrm{min}$ で行った。 圧密試験は直 径 $6 \mathrm{~cm}$, 高さ $2 \mathrm{~cm}$ の柱供試体を用い，ひずみ速度は試 料の塑性指数に応じて地盤工学会基準 ${ }^{18)}$ に基づき決定し た.

\section{3. 試料の物理特性と骨格構造}

\section{（1）物理特性の相関性}

実験に用いた試料の物理的特性を把握する目的で, 図-2に粘土分含有率 $P_{\mathrm{c}}$ と細粒分含有率 $F_{\mathrm{c}}$ の関係, 図-3に 塑性指数 $I_{\mathrm{p}}$ と粘土分含有率 $P_{\mathrm{c}}$ の関係を示した。図-2にお いて，粘土分含有率は細粒分含有率に応じて増加し，そ の割合は鳥取シルト混合土，小野田粘土混合土，有明粘 土混合土の順で大きくなっている．図-3において，小野 田粘土混合土，有明粘土混合土の塑性指数は粘土分含有 率との対応関係がみられるが，有明粘土混合土の方が高 い活性を示している。一方，鳥取シルト混合土は，すべ ての試料でNPを示している.

\section{(2) 試料の骨格構造}

飽和状態の混合土の組成は，図-4の模式図に示すよう に砂粒子骨格を形成する粗粒子(砂粒子), 細粒子(粘土粒 子, シルト粒子), 水の3つに区分して考えられる ${ }^{12)}$.こ れらの体積比から間隙比 $e$, 砂骨格間隙比 $e_{\mathrm{s}}$, 砂・シル 卜骨格間隙比 $e_{\mathrm{sm}}$ を定義し，砂骨格の形成する領域を明 確にするための間隙量の評価として用いた.

間隙比 $e$ は, 固体部の体積 $V_{S s}$ と $V_{S f}$ の和と間隙部の体 積 $V_{W}$ の比により次式で求められる.

$$
e=\frac{V_{W}}{V_{S s}+V_{S f}}
$$

また，砂粒子が骨格を形成し，細粒土を間隙とみなす 砂骨格間隙比 $e_{\mathrm{s}}$ は，間隙部の体積 $V_{W}$ と細粒子の体積 $V_{S f}$ の和を，砂粒子骨格の体積 $V_{S S}$ で除した次式で定義され る. 


$$
e_{\mathrm{s}}=\frac{V_{W}+V_{S f}}{V_{S s}}
$$

さらに，砂・シルトが骨格を形成し，粘土分を間隙と みな寸砂・シルト骨格間隙比 $e_{\mathrm{sm}}$ は，次式で定義される。

$$
e_{\mathrm{sm}}=\frac{V_{W}+V_{S c}}{V_{S s}+V_{S m}}
$$

次に，試料骨格構造と細粒分含有率の関係を調べる目 的で，間陌比 $e$, 砂骨格間隙比 $e_{\mathrm{s}}$, 砂・シル卜骨格間隙 比 $e_{\mathrm{sm}}$ と細粒分含有率の関係を，それぞれ図-5，6，7 に 示した. ここでの間隙比は，表-1 に示した三軸圧縮試

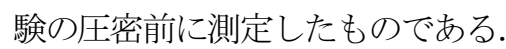

図-5に，三軸圧縮試験に用いた供試体の間隙比 $e$ と 細粒分含有率 $F_{\mathrm{c}}$ の関係を示した. 細粒分の種類によっ て異なるが，細粒分含有率の増加に伴い間隙比は, $F_{\mathrm{c}}=20 \sim 30 \%$ 位まで減少傾向であるが，それ以降は細粒 分含有率の増加に伴い大きくなっている，その傾向は細 粒土単体の間隙比に対応し，有明粘土混合土が最も大き く, 次いで小野田粘土混合土，鳥取シルト混合土の順に なっている.

図-6 に，三軸圧縮試験に用いた供試体の砂骨格間隙 比 $e_{\mathrm{s}}$ と細粒分含有率 $F_{\mathrm{c}}$ との関係を示した. 図中には, 珪砂の最大間隙比 $e_{\max }=0.85$ に相当する值を太線で示した. 表-1 及び図-6 より, 砂骨格間隙比 $e_{\mathrm{s}}$ が，珪砂の最大間 隙比 $e_{\max }=0.85$ と交わる細粒分含有率 $F_{\mathrm{c}}$ は, 各混合土と も 10～15\%程度であることが認められる．このことから， 細粒分含有率 $F_{\mathrm{c}}$ が $15 \%$ 程度以下では，粗粒子が骨格を 形成しているが，15\%程度を上回ると粗粒子の骨格が失 われ始めるものと考えられる。

図-7に，三軸圧縮試験に用いた供試体の砂・シルト 骨格間隙比 $e_{\mathrm{sm}}$ と細粒分含有率 $F_{\mathrm{c}}$ の関係を示した。鳥取 シルトはそのほとんどがシルトで構成されているため, 砂・シルト骨格間隙比 $e_{\mathrm{sm}}$ の大きさは変化が少ないのに 対し，小野田粘土混合土，有明粘土混合土は細粒分含有 率の増加に対する増加がみられ，特にシルト分の少ない 有明粘土混合土においては増加傾向が顕著である.

\section{4. 圧縮特性}

\section{（1）圧縮指数について}

圧縮特性は，定ひずみ速度圧密試験による $e-\log p$ 関係 を基に，圧縮指数 $C_{\mathrm{c}}$ と物理特性の相関性に着目して整 理を行った. 図-8(a)，(b)，(c)に，鳥取シルト混合土， 小野田粘土混合土，有明粘土混合土による $e-\log p$ 関係を それぞれ示した。鳥取シルト混合土の $e-\log p$ 関係におい

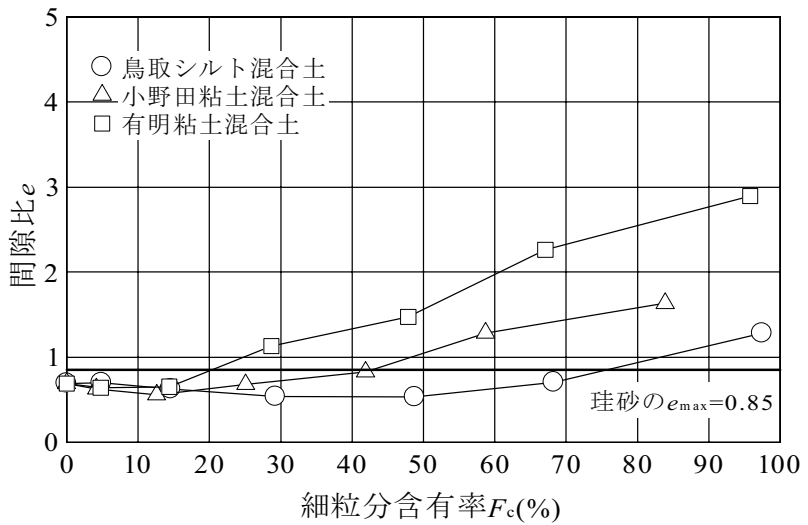

図-5 間隙比 $e$ と細粒分含有率 $F_{\mathrm{c}}$ の関係

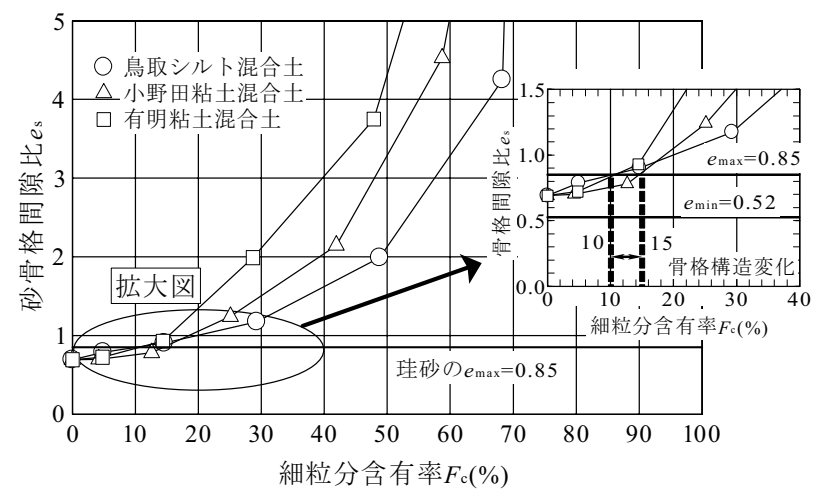

図一6 砂骨格間隙比 $e_{\mathrm{s}}$ と細粒分含有率 $F_{\mathrm{c}}$ の関係

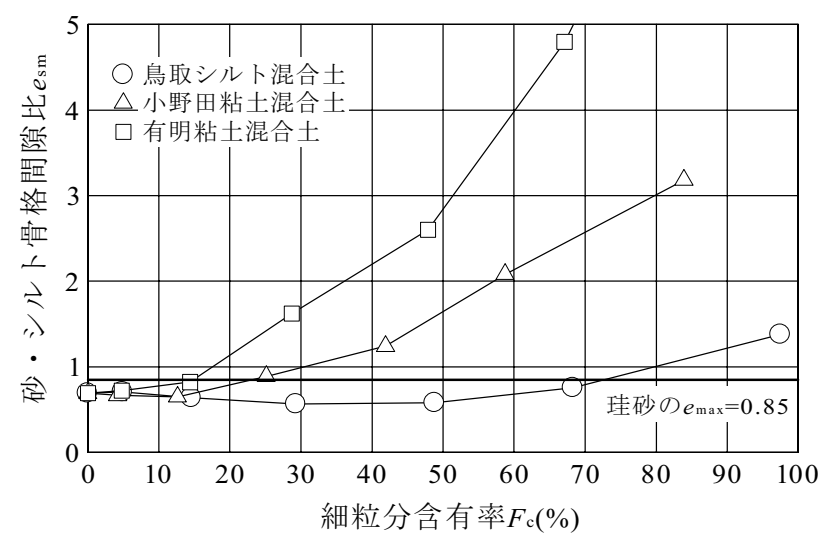

図一7 砂・シルト骨格間隙比 $e_{\mathrm{sm}}$ と細粒分含有率 $F_{\mathrm{c}}$ の関係

ては，細粒分含有率 $F_{\mathrm{c}}=70 \%$ 付近以上で間隙比の増加が みられるが，圧密圧力の増加に対寸る圧縮量は細粒分含 有率による違いが顕著でない，一方小野田粘土混合土及 び有明粘土混合土は，細粒分含有率 $F_{\mathrm{c}}=50 \%$ 付近から間 隙比が急激に増大し圧縮量も大きくなっている.

図-9 に圧縮指数 $C_{\mathrm{c}}$ と細粒分含有率 $F_{\mathrm{c}}$ の関係を示し, 各混合土の圧縮性の比較を行った. ここでの圧縮指数は, $e-\log p$ 関係における圧密圧力 $100 \mathrm{kPa}$ から 1000kPa におけ る圧力増分と，これに対応する間隙比の差の比から算出 した. 圧縮指数はいずれの混合土においても細粒分含有 率に対する増加がみられ，その割合は有明粘土混合土が 


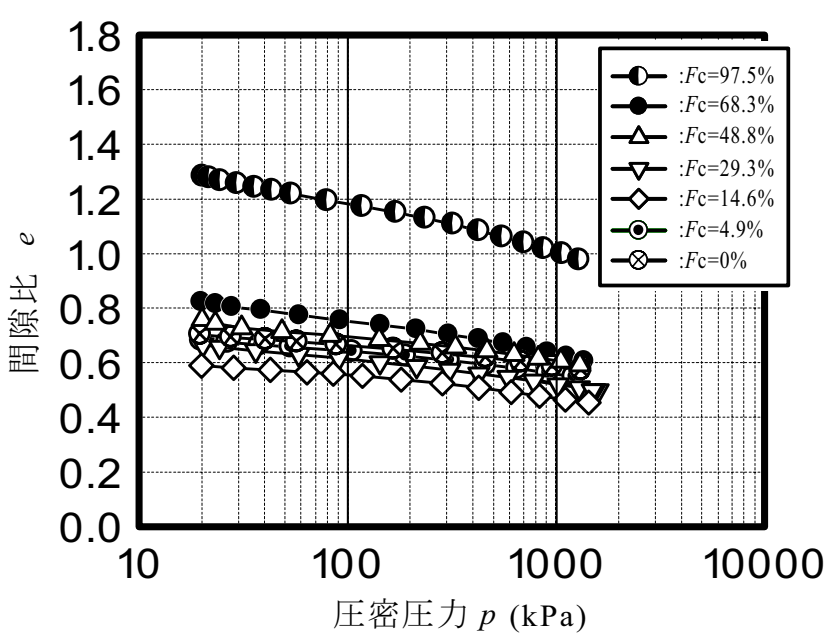

(a) 鳥取シルト混合土

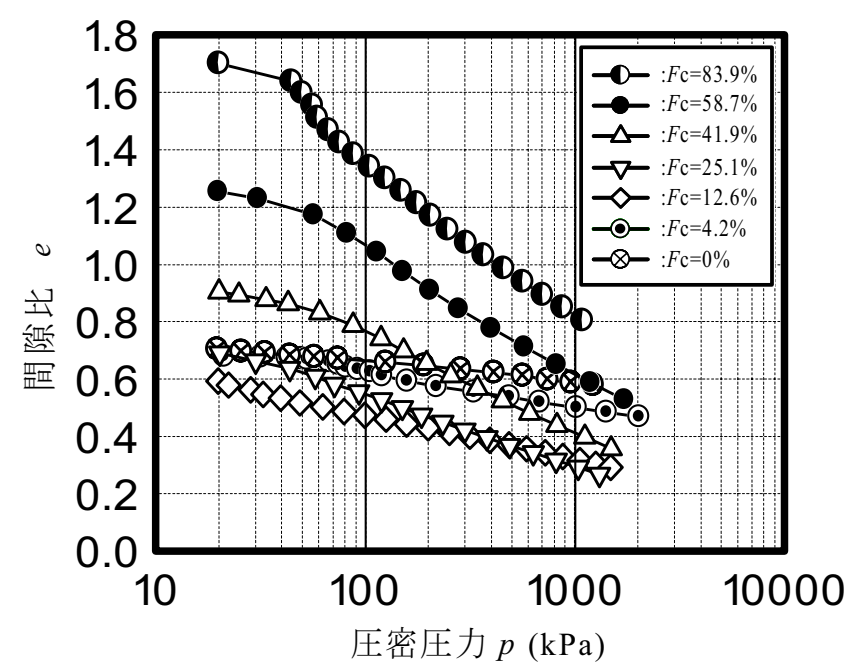

(b) 小野田粘土混合土

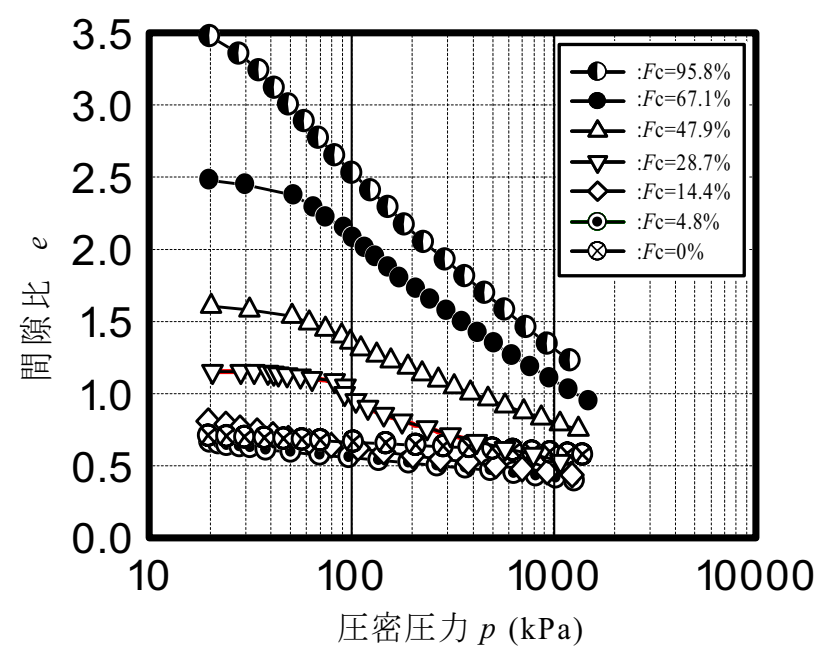

(c) 有明粘土混合土

図-8 各混合土の $e-\log p$ 関係

最も大きく，次いで，小野田粘土混合土，鳥取シルト混 合土の順となっている. 図-10 には，圧縮指数 $C_{\mathrm{c}}$ と粘土 分含有率 $P_{\mathrm{c}}$ の関係を示した. 図より, 細粒土の種類に

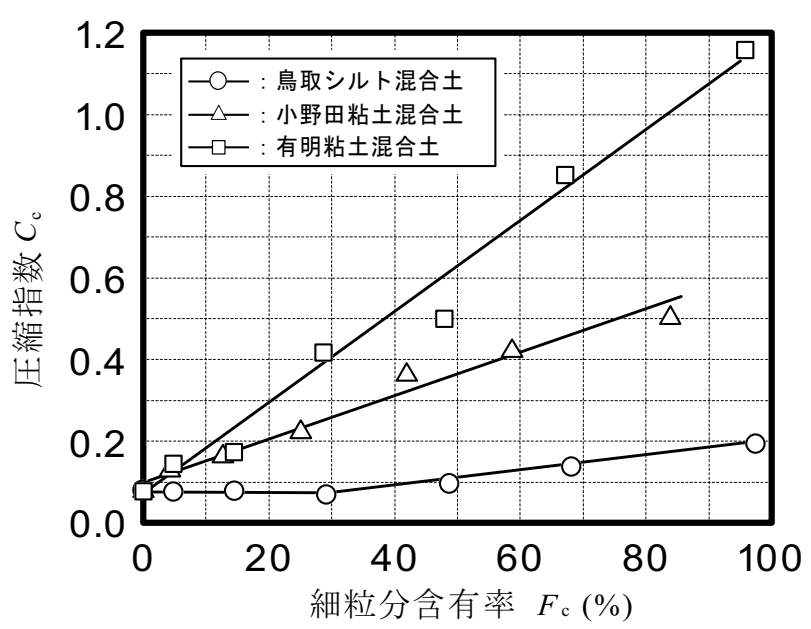

図-9 圧縮指数 $C_{\mathrm{c}}$ と細粒分含有率 $F_{\mathrm{c}}$ の関係

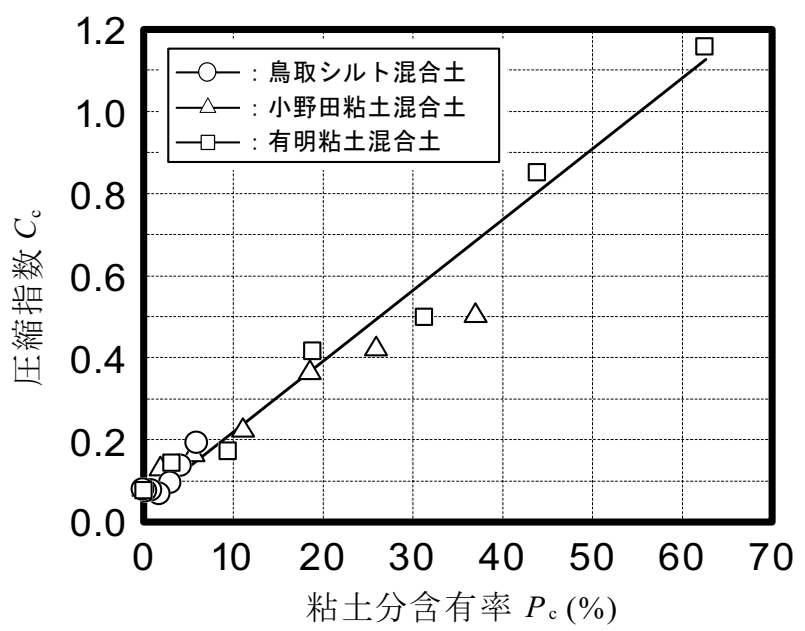

図-10 圧縮指数 $C_{\mathrm{c}}$ と粘土分含有率 $P_{\mathrm{c}}$ の関係

よらず, 混合土の圧縮指数は粘土分含有率と一義的関係 にあることが認められる。

\section{（2）体積圧縮係数について}

図-11 に，代表として圧密圧力 200kPa 時の体積圧縮係 数 $m_{\mathrm{v}}$ と細粒分含有率 $F_{\mathrm{c}}$ の関係を示した. 図中に示寸珪 砂は, 細粒分含有率 $F_{\mathrm{c}}=0 \%$ 砂のみの結果であり, す心゙ ての混合土に共通寸るものである，鳥取シルト混合土の 体積圧縮係数は, 細粒分含有率によらず $10^{-3} \mathrm{~m}^{2} / \mathrm{kN}$ 程度 を示している. 小野田粘土混合土及び有明粘土混合土の 体積圧縮係数は, 細粒分含有率 $F_{\mathrm{c}}=30 \%$ 付近まで急激に 増加した後, 徐々に増加寸る傾向を示している.

図-12 に, 圧密圧力 $200 \mathrm{kPa}$ 時の体積圧縮係数 $m_{\mathrm{v}}$ と粘 土分含有率 $P_{\mathrm{c}}$ の関係を示した. 同図より各混合土の体 積圧縮係数は, 粘土分含有率 $P_{\mathrm{c}}=15 \%$ 付近まで急激に増 加した後緩やかな増加傾向を示している.このことから， 混合土の体積圧縮係数は細粒分含有率 $F_{\mathrm{c}}=30 \%$ 付近もし くは粘土分含有率 $P_{\mathrm{c}}=15 \%$ 付近までは粗粒子骨格の影 


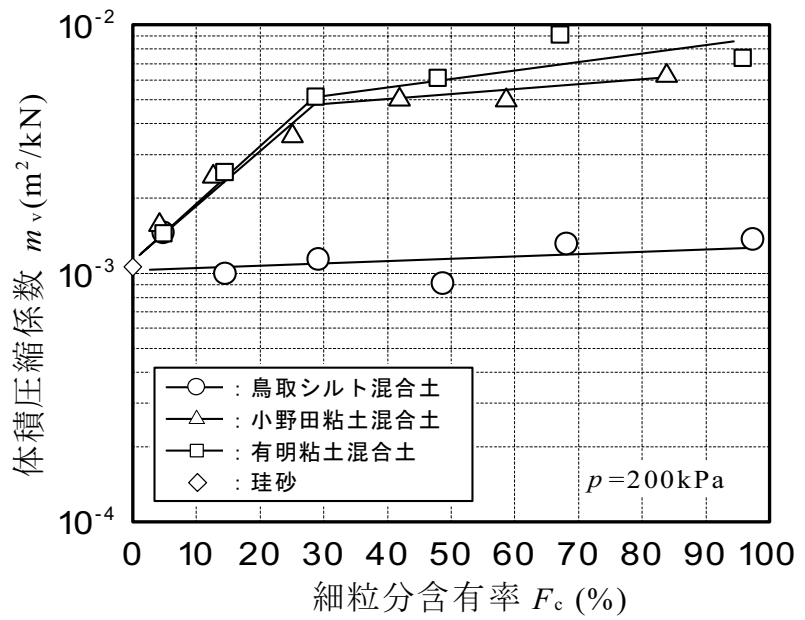

図-11 体積圧縮係数 $m_{\mathrm{v}}$ と細粒分含有率 $F_{\mathrm{c}}$ の関係

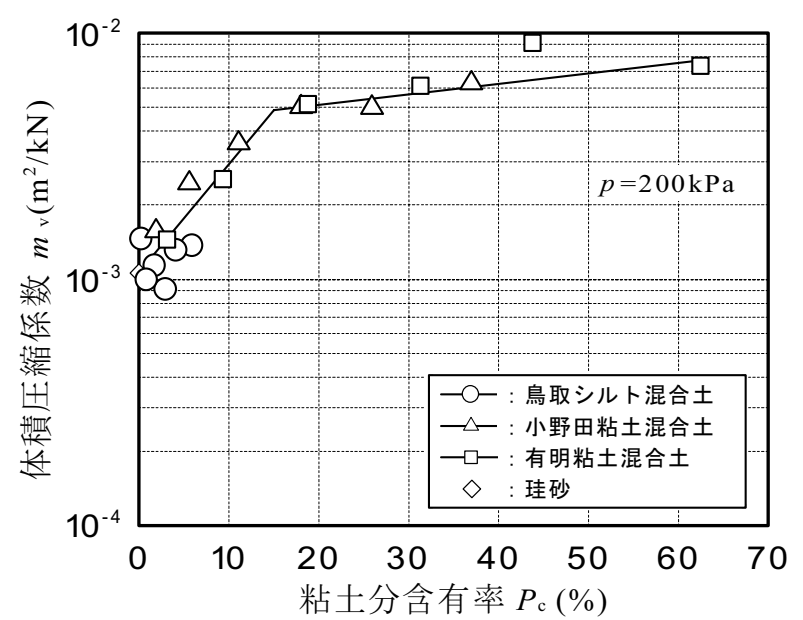

図-12 体積圧縮係数 $m_{\mathrm{v}}$ と粘土分含有率 $P_{\mathrm{c}}$ の関係

響を受けるが，それ以降では細粒土主体の構造に移行し， 圧縮特性も細粒分の性質を示していくことが確認された.

\section{（3）圧密係数について}

図-13 に，代表として圧密圧力 $200 \mathrm{kPa}$ 時の圧密係数 $C_{\mathrm{v}}$ と細粒分含有率 $F_{\mathrm{c}}$ の関係を示した。鳥取シルト混合 土の圧密係数は，細粒分含有率 $F_{\mathrm{c}}=30 \%$ 付近まで緩やか に減少した後, $10^{4} \mathrm{~cm}^{2} / \mathrm{day}$ 程度で一定值を示している. 一方，小野田粘土混合土及び有明粘土混合土の圧密係数 は，細粒分含有率 $F_{\mathrm{c}}=30 \%$ 付近まで大きく低下し，その 後緩やかな減少傾向を示している.

図-14 に，圧密圧力 $200 \mathrm{kPa}$ 時の圧密係数 $C_{\mathrm{v}}$ と粘土分 含有率 $P_{\mathrm{c}}$ の関係を示した. 圧密係数は混合土の違いに よらず，粘土分含有率 $P_{\mathrm{c}}=15 \%$ 付近までは大きく低下し た後, 粘土分含有率の増加に伴い徐々に低下していく傾 向を示し，体積圧縮係数の場合と同样の傾向を示した. 圧密係数は透水係数と関連があり，シルトを主体とする 鳥取シルト混合土は，小野田粘土混合土及び有明粘土混 合土に比べて高い透水性を有していると判断される.

以上の結果から, 混合土の圧縮特性は, 粘土分含有率

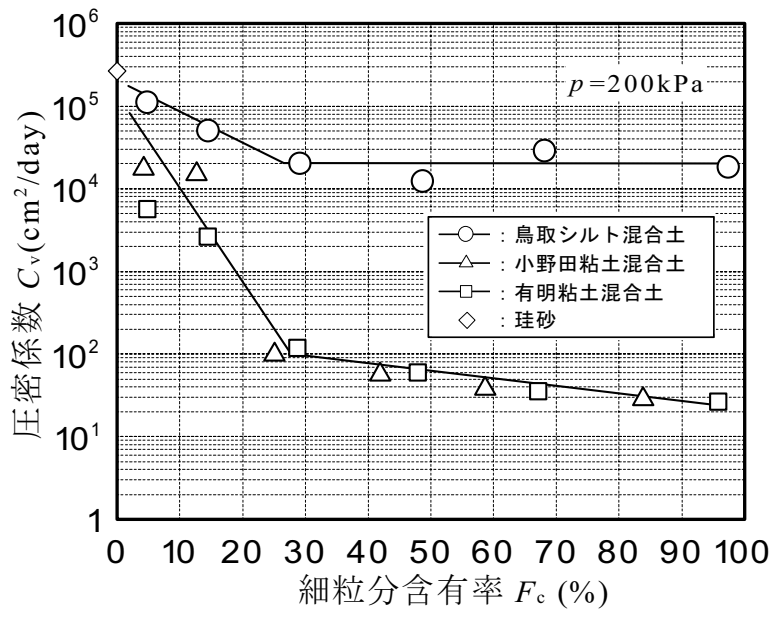

図-13 圧密係数 $C_{\mathrm{v}}$ と細粒分含有率 $F_{\mathrm{c}}$ の関係

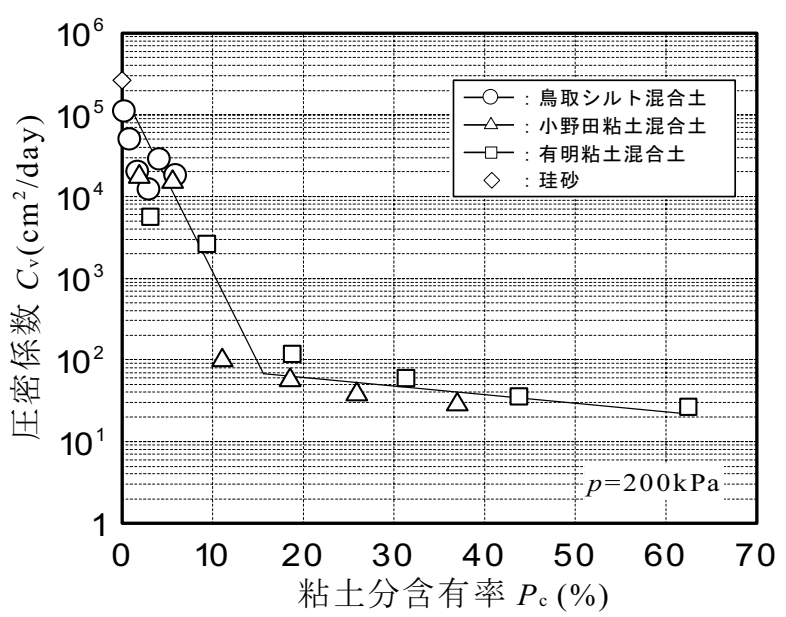

図-14 圧密係数 $C_{\mathrm{v}}$ と粘土分含有率 $P_{\mathrm{c}}$ の関係

と概ね一義的関係が認められる，これは，細粒土の中に は, 塑性を有する粘土鉱物から成る成分や, 砂の粉砕し た細粒分などが混入していると考えられ，粒度特性にお ける粘土分 $(0.005 \mathrm{~mm}$ 以下)においては，スメクタイトな どの粘土鉱物が卓越すると考えられる．したがって，圧 密における圧縮指数や圧密係数などは，このような粘土 鉱物の割合によるところが大きいものと考えられる.

\section{5. せん断特性}

（1）有効応力経路，軸差応力-軸ひずみ関係

図-15 に鳥取シルト混合土の非排水三軸圧縮試験より 得られた (a) 有効応力経路，(b) 軸差応力-軸ひずみ関係 を示した. 図-16 に小野田粘土混合土の (a) 有効応力経 路，(b)軸差応力-軸ひずみ関係，図-17 に有明粘土混合 土の (a) 有効応力経路， (b) 軸差応力-軸ひずみ関係を示 した。 なお，各供試体の間隙比は表-1 に掲げた值であ る.

鳥取シルト混合土は，すべての試料において載荷初期 


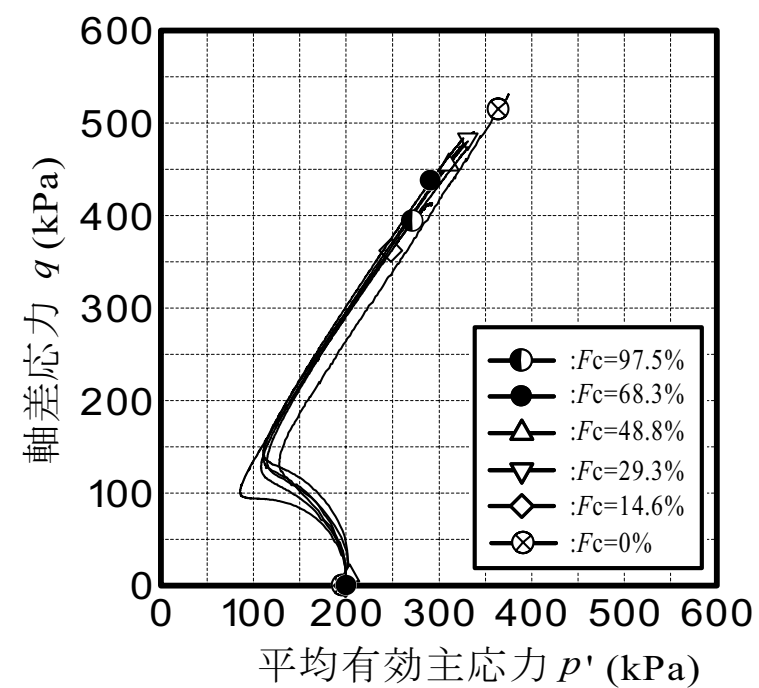

(a) 有効応力経路

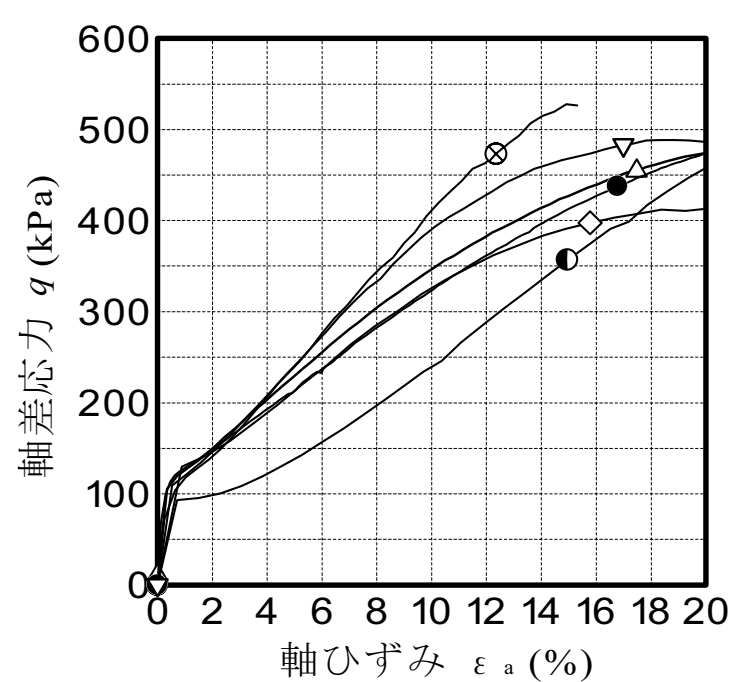

(b) 軸差応力-軸ひずみ関係

図-15 鳥取シルトの非排水せん断挙動

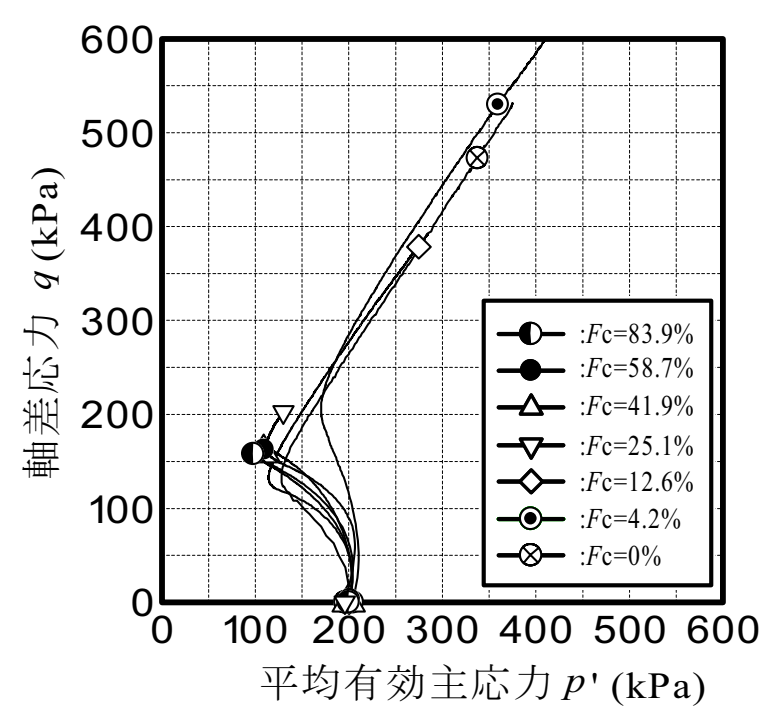

(a) 有効応力経路

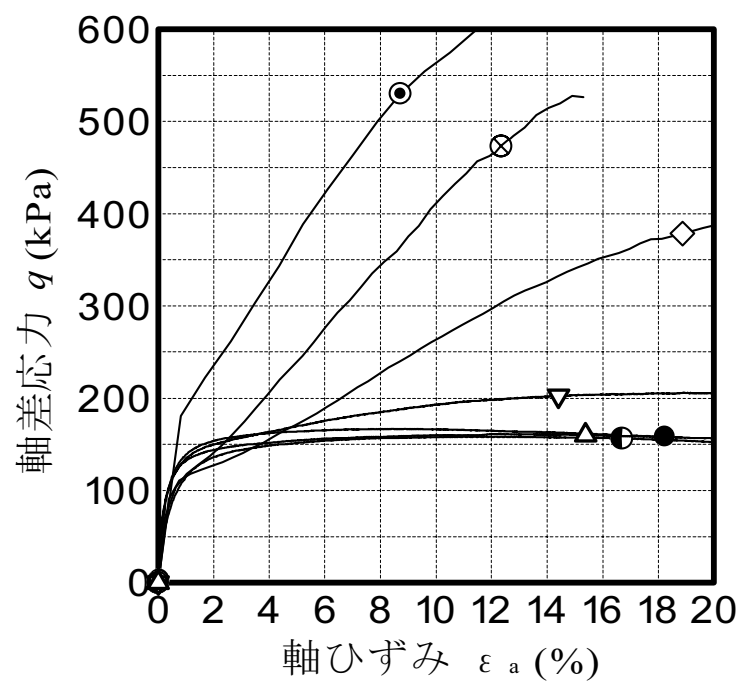

(b) 軸差忘力-軸ひずみ関係

図-16 小野田粘土の非排水せん断挙動

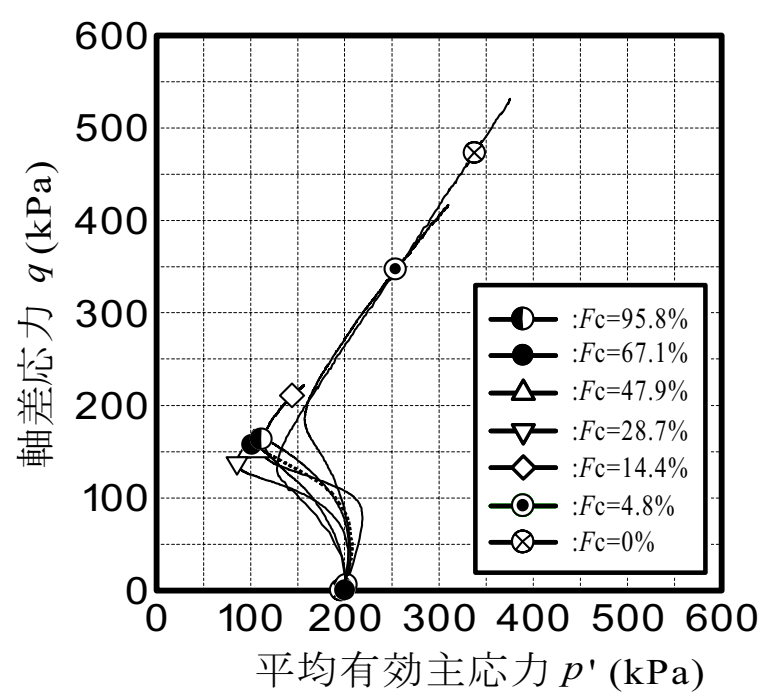

(a) 有効応力経路

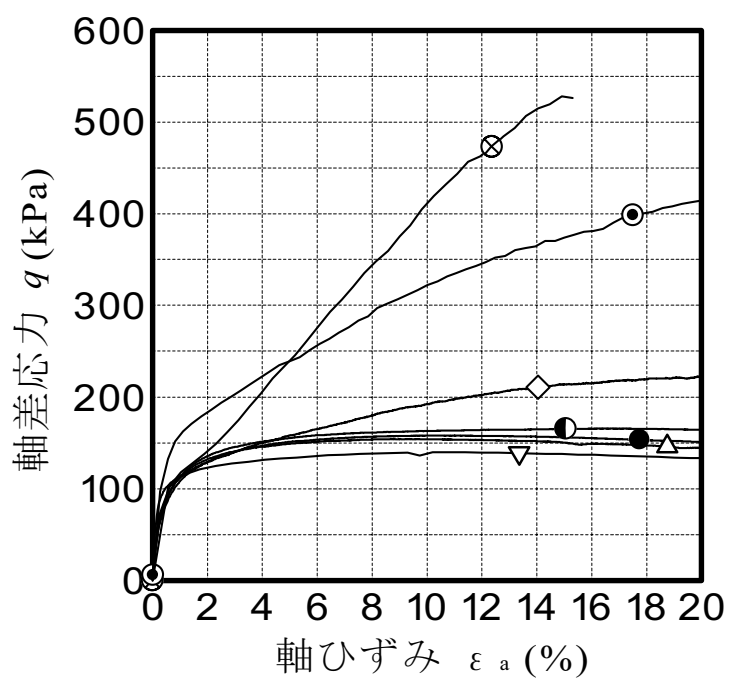

(b) 軸差応力-軸ひずみ関係

図-17 有明粘土の非排水せん断挙動 


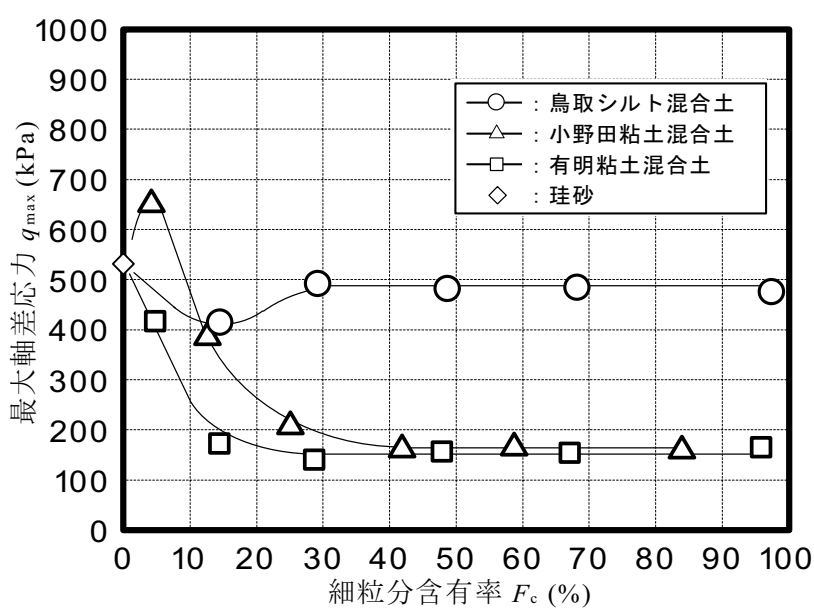

図-18 最大軸差応力 $q_{\max }$ と細粒分含有率 $F_{\mathrm{c}}$ の関係

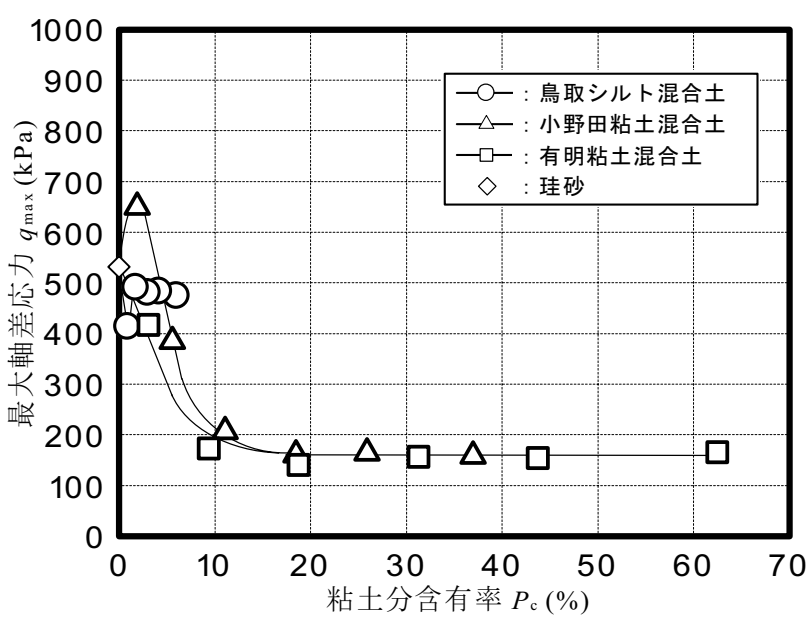

図-19 最大軸差応力 $q_{\text {max }}$ と粘土分含有率 $P_{\mathrm{c}}$ の関係

に収縮傾向をとり，変相点に至った後，正のダイレイタ ンシーによる強度増加を示す．軸差応力-軸ひずみ関係 において，軸差応力は軸ひずみ $1 \%$ 付近まで急増し，そ の後緩やかな上昇挙動を示している.

小野田粘土混合土においては，細粒分含有率 $F_{\mathrm{c}}=30 \%$ 以下では変相点を示し, その後顕著な正のダイレイタン シーによる強度増加を示している．軸差応力・軸ひずみ 関係においては，軸ひずみ $1 \%$ 付近までの軸差応力の急 増とその後の漸増傾向が特徵的である. 一方, 細粒分含 有率 $F_{\mathrm{c}}=50 \%$ 以上においては収縮のみの挙動を示し，軸 差応力は軸ひずみ $1 \%$ 付近までは急増した後, ほぼ定常 状態に至る様子が観察される.

有明粘土混合土では, 細粒分含有率 $F_{\mathrm{c}}=15 \%$ 以下の混 合土において変相点を示し，その後顕著な正のダイレイ タンシーによる強度増加がみられる。一方，細粒分含有 率 $F_{\mathrm{c}}=30 \%$ 以上になると収縮のみの挙動を示し, 軸差応 力も初期に急増した後, 定常状態を示している.

\section{（2）最大軸差応力と物理特性の関係}

それぞれの混合土のせん断試験から得られたせん断強

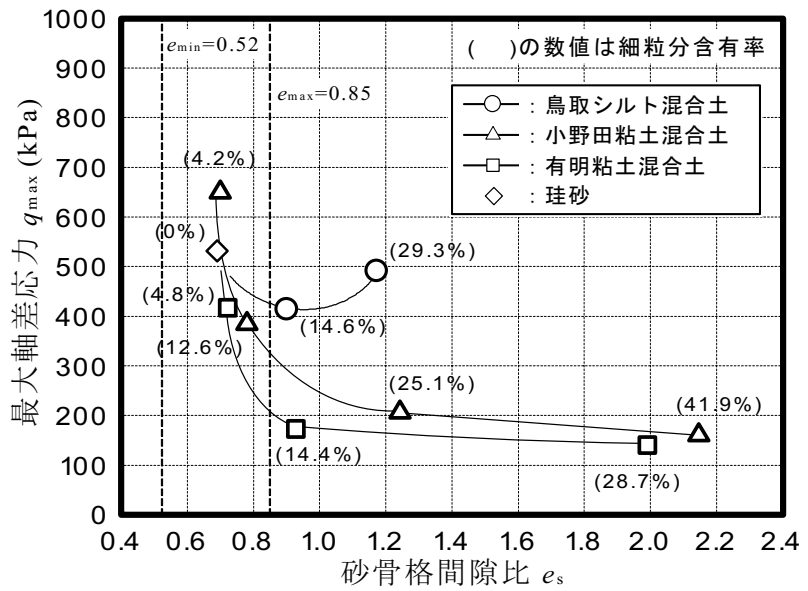

図-20 最大軸差応力 $q_{\max }$ と砂骨格間隙比 $e_{\mathrm{s}}$ の関係

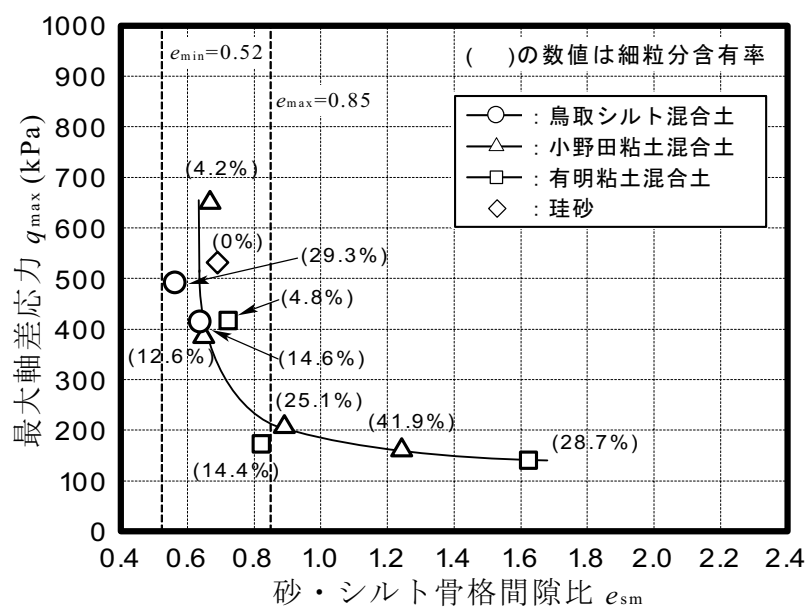

図-21 最大軸差応力 $q_{\max }$ と砂・シルト骨格間隙比 $e_{\mathrm{sm}}$ の関係

度と物理特性の関係を調べる目的で，図-18 に最大軸差 応力 $q_{\text {max }}$ と細粒分含有率 $F_{\mathrm{c}}$ の関係を示した. ここでの 最大軸差応力は, 軸差応力-軸ひずみ曲線における, 軸 ひずみ $\varepsilon_{\mathrm{a}}=20 \%$ までの最大值を採用した。この理由は, 最大軸差応力は，軸差応力-軸ひずみ関係が細粒分含有 率により異なる状況から，定常状態に準じたひずみ領域 $20 \%$ 付近での最大值とした.

図-18 において，鳥取シルト混合土の最大軸差応力は 終始 400〜 500kPa を示し, 細粒分含有率に対する変化は さほどみられない，一方，小野田粘土混合土の最大軸差 応力は, 細粒分含有率 $F_{\mathrm{c}}=5 \%$ において増加し, それ以上 の細粒分含有率では減少し $F_{c}=40 \%$ 付近から $200 \mathrm{kPa}$ 程度 で一定值を示している．また，有明粘土混合土の最大軸 差応力は細粒分含有率の増加に伴い減少し, 細粒分含有 率 $F_{\mathrm{c}}=30 \%$ 以上で $200 \mathrm{kPa}$ 程度となりその後一定值を示し ている，同図において，小野田粘土混合土と有明粘土混 合土は，細粒分含有率の高い部分ではほぼ等しい強度を 示したが，鳥取シルト混合土は異なる強度となっている。

図-19 は, 最大軸差応力 $q_{\text {max }}$ を粘土分含有率 $P_{\mathrm{c}}$ との関 係でまとめたものである. 図において，鳥取シルト混合 
土の粘土分含有率は $6 \%$ 以下であるため, 分布範囲が狭 くなっている. 小野田粘土混合土の最大軸差応力は, 粘 土分含有率 $P_{\mathrm{c}}=5 \%$ 付近まで上昇した後低下し, 粘土分含 有率 $P_{\mathrm{c}}=20 \%$ 以上で $200 \mathrm{kPa}$ 程度に達しその後一定値とな っている. また，有明粘土混合土においては，粘土分含 有率 $P_{\mathrm{c}}$ の増加に伴い最大軸差応力は減少し, $P_{\mathrm{c}}=20 \%$ 以 上では小野田粘土混合土と同一の強度を示している．混 合土のせん断特性は圧縮特性と同様, 粘土分含有率 $P_{\mathrm{c}}=15 \%$ 付近で変化し，これに対応する細粒分含有率は $F_{\mathrm{c}}=30 \%$ 付近となっている.

前述のとおり, 混合土の骨格構造は, 細粒分含有率 $F_{\mathrm{c}}=15 \%$ 以上において徐々に崩れ始めるが, $F_{\mathrm{c}}=30 \%$ 付近 以上でほとんど完全に失われ，細粒土主体の構造に移行 することを裏付ける結果となった.

\section{（3）最大軸差応力と骨格間陌比の関係}

前述の圧密及びせん断特性から, 砂骨格構造の影響が 残ると考えられる細粒分含有率 $F_{\mathrm{c}}=30 \%$ 以下の混合土を 対象に，せん断強度と砂骨格間隙比 $e_{\mathrm{s}}$ ，砂・シル卜骨格 間隙比 $e_{\mathrm{sm}}$ との関連性について検討を行う。なお小野田 粘土においては, グラフの推移をみるために ONO$50\left(F_{\mathrm{c}}=41.9 \%\right)$ の結果もプロットした.

図-20に，珪砂及びそれぞれの混合土の最大軸差応力 $q_{\text {max }}$ と砂骨格間隙比 $e_{\mathrm{s}}$ の関係を示した. また, 各プロッ 卜傍の括弧内に各試料の細粒分含有率を示した。 小野田 粘土混合土の最大軸差応力は, その砂骨格間隙比が珪砂 の最大間隙比 $e_{\max }=0.85$ より小さいところでは大きな值を 示寸が，最大間隙比を上回ると急激に低下し，さらに砂 骨格間隙比 $e_{\mathrm{s}}=1.2$ 付近で粘土単体とほぼ同じ大きさの強 度に至っている. この傾向は，有明粘土混合土でも同様 に確認される，一方，鳥取シルト混合土は砂骨格間隙比 に対する変化があまりみられない，

次に図-21に, 最大軸差応力 $q_{\text {max }}$ と砂・シルト骨格間 隙比 $e_{\mathrm{sm}}$ の関係を示した. 最大軸差応力は, 砂・シルト 骨格間隙比の増加に伴い低下し，鳥取シルト混合土，小 野田粘土混合土，有明粘土混合土寸べてに対し，ほぼ一 義的関係が認められる.このことより, 細粒分含有率 $F_{\mathrm{c}}=30 \%$ \%下における混合土のせん断強度は, 砂骨格だ けでなくシルト分の影響も無視できないことが判明し， 砂・シルト骨格間隙比により混合土のせん断強度に対す る統一的な評価が可能と考えられる.

砂・シルト骨格間隙比は, 砂とシルトが骨格構造を形 成し，粘土と水を間隙とみなしたものである. 混合土の せん断特性は細粒分の種類に応じ，砂の骨格主体から細 粒土主体一と変化する，すなわち，細粒土に含まれるシ ルト分は, 粘土分よりも砂骨格に寄与寸る可能性が高い と考えられる. 特に, 鳥取シルト混合土は非活性のシル
トを多く含み，それらのシルトは砂と共に骨格構造を形 成すると考えられる.

\section{6. まとめ}

本研究では，3種類の塑性の異なる細粒土と粒度調整 した珪砂を様々な割合で混合し,多様な混合土を作製し て一連の定ひずみ速度圧密試験と非排水三軸圧縮試験を 行った. 本研究で得られた知見をまとめると, 以下のと おりである。

1） 圧縮指数 $C_{\mathrm{c}}$ と粘土分含有率 $P_{\mathrm{c}}$ の関係は, 塑性の異な る細粒土を含む混合土すべてが一つの直線関係とな り，混合土に含まれる細粒土の塑性の有無に関わら ず包括的に評価可能である.

2）塑性を有する細粒分から成る混合土の体積圧縮係数 $m_{v}$, 圧密係数 $C_{\mathrm{v}}$ は, 砂の骨格構造の影響を受け, 細 粒分含有率 $F_{c}=30 \%$ 付近, また粘土分含有率 $P_{\mathrm{c}}=15 \%$ 付近で特性が変化する.

3）混合土のせん断特性も，圧縮特性と同様砂の骨格構 造が変化する細粒分含有率 $F_{\mathrm{c}}=30 \%$ 付近, また粘土 分含有率 $P_{\mathrm{c}}=15 \%$ 付近で変化する.

4）混合土の骨格構造は，砂骨格間隙比が珪砂の最大間 隙比以上で崩れ始め, 細粒分含有率 $F_{\mathrm{c}}=30 \%$ 程度ま でには砂骨格の影響が消失し, 細粒土の特性が支配 的になる.

5）細粒分含有率 $F_{\mathrm{c}}$ が $30 \%$ 以下における混合土のせん断 強度は, 砂・シルト骨格間隙比により統一的に評価 が可能と考えられる.

謝辞 : 本研究を行うに当たって, 山口大学大学院理工学 研究科博士前期課程の難波宏文氏 (現 岡山市)には, 実 験の遂行に多大なる労を頂いた。 ここに深く感謝の意を 表する次第である.

\section{参考文献}

1)地盤工学会 : ジオテクノート 2 中間土一砂か粘土かー, 1992.

2) 鬼塚克忠, 吉武茂樹 : 粘土・砂の飽和混合土の圧縮特性, 土 之基礎，第 34巻，第7号，pp.73-79, 1986.

3) 中瀬明男, 日下部治, 亀井健史, 鈴木弘之: 粘性土地盤の異方 性と塑性指数, 土と基礎，第 32 巻，第 11 号, pp. 19-24, 1984.

4) Trollope, D. H. and Zafar, S. M. : A study of the shear strength of saturated sand, and sand/clay mixtures, in triaxial compression, Proc., 2nd AustraliaNewzealand Conf. S. M. F. E.,pp. 7-16, 1965.

5) 倉田進，藤下利夫 : 砂と粘土の工学的性質に関寸る研究，運 輸省港湾技術研究所報告,Vol. 11,No. 9, pp. 389-424, 1961.

6) Georgiannou, V. N., Burland, J. B. and Hight, D. W. : The undrained behaviour of clayey sands in triaxial compression and extension, Gotechnique, Vol. 40, No. 3,pp. 431-449, 1990.

7) Georgiannou, V. N., Hight, D. W. and Burland, J. B. : Undrained 
behaviour of natural and model clayey sands, Soils and Foundations, Vol. 31,No.3,pp. 17-29, 1991.

8）日本港湾協会 : 港湾の施設の技術上の基準・同解説，pp. 241$245,1999$.

9) Lade, P. V. and Yamamuro, J. A. : Effects of nonplastic fines on static liquefaction of sands, Can. Geotech. J., Vol.34,pp. 918-928, 1997.

10) 福江正治, 大草重康 : 砂と粘土の混合土の工学的性質の新 しい評価手法について, 東海大学紀要海洋学部, 第 14 号, pp. 247-261, 1981.

11) 八尾真太郎，平田茂良 : 中間土の強度発現機構に関する考 察（その 2)，第 25 回土質工学研究発表会講演概要集, pp. 701-704, 1990 .

12) 大嶺聖，落合英俊 : 二種混合体の応力-ひずみ関係と混合土 の一次元圧縮特性一の適用，土木学会論文集，No.448/III-19, pp. 121-130, 1992.

13) 黄大振，柳沢英司，菅野高弘：シルトを含む砂のせん断特 性について，土木学会論文集，No.468/III-22,pp.25-33, 1993.
14) 伊東周作, 兵動正幸, 藤井照久, 山本陽一, 谷口聡一： 砂・粘土・中間土の非排水単調及び繰返しせん断特性, 土木学会論文集, No. 680/III-55,pp. 233-243, 2001.

15) 吉本憲正, 兵動正幸, 藤井照久, 山本陽一, 伊東周作 : 2000 年鳥取県西部地震で液状化した細粒土の諸特性につい て，土木学会論文集，No.722/III-61,pp. 85-96, 2002.

16) 山田卓, 兵動正幸, 中田幸男, 吉本憲正, 村田秀一 : 広範 な粒度と塑性を有する土の動的変形特性, 土木学会論文集, No. 806/III-73, pp. 155-168, 2005.

17) 兵動正幸，金鐘根，福本圭祐，山田卓，吉本憲正 : 初期せ ん断応力を受ける砂粘土混合土の非排水繰返しせん断挙動, 土木学会論文集 C, Vol.62, No.1,pp.240-245,2006.

18) 土質試験の方法と解説(第一回改訂版) : (社)地盤工学会, p. 392,2000 .

(2007.6. 19受付)

\title{
COMPRESSION AND UNDRAINED SHEAR CHARACTERISTICS OF SAND-FINES MIXTURES WITH VARIOUS PLASTICITY
}

\author{
Yoshio KONISHI, Masayuki HYODO and Shusaku ITO
}

Three kind of marine clays with various plasticity and silica sand were mixed at different proportions, and specimens were prepared either by water sedimentation or by pre-consolidation. Then, a series of consolidation and undrained shear tests were performed on the specimens. Thus, soil samples with broad grain size distribution, i.e. ranging from sand to clay, were formed and, based on the test results, a unified method to evaluate the undrained shear strength of sand-clay mixtures was proposed. When the fines content is low, a soil mixture is formed such that the sand particles form the soil matrix while the finer particles occupy the void spaces in between. The strength of the soil mixture is dependent on the void ratio formed by the sand matrix. On the other hand, when the fines content is increased up to a certain point, the fines dominate the matrix structure of the soil, with the coarse sand particles scattered around, resulting in the strength of the mixture being controlled by the characteristics of the finer particles. 